Al-Azhar Bull. Sci. Vol. 18, No. 1 (June.): pp. 115-132, 2007.

\title{
EFFECT OF FLY-ASH AND SILICA FUME ON THE PROPERTIES OF CONCRETE EXPOSED TO HIGH TEMPERATURE
}

\author{
M.A.TAHER
}

Faculty of Science, Chemistry Dept., Al-Azhar University, Assiut, Egypt.

\begin{abstract}
The development of high concrete temperatures could cause a number of effects that have been shown to be determined to long-term concrete performance. High concrete temperatures increase the rate of hydration, thermal stresses, the tendency for drying shrinkage cracking, permeability, and decrease of long-term concrete strengths and durability as a result of cracking. The objective of this study is to investigate the effects of using fly ash and silica fume on the strength and absorption of cement concrete and pozzolanic cement concrete in hot condition. The cement concrete and pozzolanic cement concrete specimens containing fly-ash or silica fume were first cured in water for different periods 1, 3, 7, 28, 90 and 180 days then exposed to high temperature $45^{\circ} \mathrm{C}$ ( maximum summer temperature in Egypt and Arabian Gulf countries) in oven for 2,8,12 and 24 hours. The effect of fly-ash and silica fume contents on the absorption capacity of concrete specimens was evaluated by measuring 48-hours absorption and volume of permeable voids. The specimens were also tested for compressive strength and moisture content. The results show an increase in the compressive strength and decrease in moisture content of cement concrete and pozzolanic cement concrete specimens with increasing both curing exposing temperature time. The absorption of these concretes decreased with time of curing and increased with exposing temperature time .The absorption of both fly-ash and silica fume cement concrete specimens decreased significantly at early stages (3-7days) of curing. While the absorption of cement concrete specimens were effected significantly by exposing temperature period, no significant change in the absorption of pozzolanic cement concretes due to increasing exposing temperature period was observed, especially after 7 days of curing. The volume of permeable voids also decreased with curing. The highest reduction in the absorption and volume of voids was observed in the fly-ash concrete specimens.
\end{abstract}

Keywords: Fly-ash, Silica fume, Concrete, Blended cement, Pozzolans.

\section{Introduction}

The manufacture of concrete with Portland cement in adverse weather conditions involving high and low temperatures directly influences the performance of the concrete during mixing, transport, casting and curing, and its physical and mechanical properties. This is of concern to both concrete manufacturers and final users, as it affects a range of technical and economic aspects. A high ambient temperature causes a higher water demand of the concrete and increases the 
temperature of the fresh concrete. This, results in an increased rate of loss of slump and in a more rapid hydration, which leads to acceleration in setting and to a lower long-term strength of concrete [1]. Besides, an increased rate of evaporation from fresh concrete results in a lower effective water content and hence lower effective water-cement ratio per weight. Moreover, concrete workability is reduced. This implies either an addition of water in order to restore the workability or an insufficient compacting [2]. Likewise in hot climates, there is a tendency for plastic cracking and crazing. As a result, a high temperature can adversely affect the mechanical properties and serviceability of hardened concrete [3]. On the other hand, the chemical processes associated to the hardening of concrete in the first days after casting are accompanied by significant temperature changes, since cement hydration is a highly exothermic and thermally activated reaction [4]. The temperature variation caused by the heat of hydration or the change of external environment has a large influence on the mechanical properties of early-age concrete. Therefore, effects of temperature and aging on the mechanical properties must be studied and quantified [5]. Curing condition and curing temperature also influence the properties of hardened concrete. If curing is neglected in the early period of hydration, the compressive strength and modulus of elasticity of concrete will decrease at later ages and suffer some irreparable loss [6]. Elevated curing temperature hinders the hydration of cement at later ages and forms an open pore structure of cement paste and therefore affects the properties of hardened concrete [7]. Silica fume is a powder by-product resulting from the manufacture of ferrosilicon and silicon metal. It has a high content of glassy of silicon dioxide $\left(\mathrm{SiO}_{2}\right)$ and consists of very small spherical particles. Because of this, it has been a popular mineral admixture to use in concrete to mitigate the durability problems in aggressive environments [8-12]. The high pozzolanic reactivity and microfiller effect of silica fume at medium temperature has modified the open channels at the transition zone in silica fume concrete. The medium temperature environment associated with proper curing has played an important role in the hydration process that produced the hardened concrete with higher strength and elasticity [13]. Fly-ash is a byproduct of coal-burning power plant. It is widely used as a cementitious material and a pozzolanic ingredient in concrete. The use of fly-ash in concrete is constantly increasing because it improves the properties of concrete, namely workability, durability, and strength in hardened concrete. Many researchers [14-16] concluded that fly-ash with a high degree of fineness was an important factor producing high-strength concrete. Mineral admixtures such as natural pozzolan, fly-ash, and blast furnace slag and silica fume are increasingly used in concrete to produce dense and impermeable concrete. The 
use of these mineral admixtures is reported to retard deterioration of concrete due to reinforcement corrosion [17,18], sulfate attack [19] and alkali-aggregate reactions [20]. Most fly-ashes, regardless of compositions, tend to reduce the water demand of concrete and increase its resistance to fluid flow and the ionic diffusion. The beneficial effect of fly-ash on permeability and diffusivity tend to become more apparent with time (maturity), especially in the case of the more slowly reacting low $\mathrm{CaO}$ fly-ashes $[21,22]$.

\section{Experimental program:}

\section{Materials:}

Materials used in this study consisted of Portland cement (PC), coarse aggregate, fly-ash (FA), silica fume (SF) and water. The cement used was ASTM type I normal Portland cement with specific gravity of $3.15 \mathrm{~g} / \mathrm{cm}^{3}$. Initial and final setting times of cement were 110 and 215 minutes, respectively. Its Blaine specific surface area was $3140 \mathrm{~cm}^{2} / \mathrm{g}$ its chemical compositions are given in Table 1 . The coarse aggregate used was crushed lime stone with $12 \mathrm{~mm}$ maximum size. The fine aggregate was natural sand; having a fineness modulus of 3.02.The coarse and fine aggregate had a specific gravity of 2.67 and $2.61 \mathrm{~g} / \mathrm{cm}^{3}$, and water absorption of $0.3 \%$ and $0.8 \%$, respectively.The fly-ash was collected from the electricity generating Shobra ElKhaima Thermal Power Station in Cairo. It is high-calcium and high-sulphate flyash. Its specific gravity was $2.7 \mathrm{~g} / \mathrm{cm}^{3}$ and Blaine specific surface area was 2900 $\mathrm{cm}^{2} / \mathrm{g}$. Its chemical composition is given in Table1. Silica fume was supplied from Ferrosilicon Alloy Plant in Kom Ambo, Aswan, Egypt. Its chemical composition is given in Table 1.The specific gravity was $2.32 \mathrm{~g} / \mathrm{cm}^{3}$

Table 1: Chemical composition of cement, fly ash and silica fume, (mass \%):

\begin{tabular}{|c|c|c|c|}
\hline Constituents & Cement(PC) & Fly ash (FA) & Silica fume (SF) \\
\hline $\mathrm{SiO}_{2}$ & 20.65 & 18.95 & 81.40 \\
$\mathrm{Al}_{2} \mathrm{O}_{3}$ & 5.60 & 7.53 & 4.47 \\
$\mathrm{Fe}_{2} \mathrm{O}_{3}$ & 4.13 & 3.82 & 1.40 \\
$\mathrm{CaO}$ & 61.87 & 51.29 & 0.82 \\
$\mathrm{MgO}$ & 2.60 & 1.58 & 1.48 \\
$\mathrm{SO}_{3}$ & 2.79 & 12.06 & 1.35 \\
$\mathrm{~K}_{2} \mathrm{O}$ & 0.83 & 1.51 & --- \\
$\mathrm{Na}_{2} \mathrm{O}$ & 0.14 & 0.32 & -- \\
Ignition loss & 1.39 & 1.94 & 7.26 \\
\hline
\end{tabular}




\section{Mix proportions:}

Table (2) shows the concrete mix proportions in this investigation. All mix proportions had the same cementitious materials of $350 \mathrm{~kg} / \mathrm{m}^{3}$, and the water to cementitious materials ratio (W/C) was 0.3 .

Three mix proportions of concrete were used in the current study. The first mix was control concrete (control) containing only PC as cementitious materials. The second mix (FAC) contained the replacement of PC by $20 \%$ FA by weight and the third mix (SFC) contained the replacement of PC by $10 \%$ SF by weight. The reason of using $20 \% \mathrm{FA}$ and $10 \% \mathrm{SF}$ in this investigation is attributed to the results obtained by Ch.Jaturapitakkul et al [23]. They found that, strength development of concrete containing FA as a cement replacement of $10 \%, 20 \%$ and $30 \%$ was faster than that $50 \%$ cement replacement, while $20 \%$ cement replacement gave the highest strength at all ages of curing. Also, they found that, using $10 \% \mathrm{SF}$ in concrete cause large improvement in compressive strength than that caused by using $5 \%$ and $15 \%$ of SF at all ages of curing.

Table 2: Concrete mix proportions:

\begin{tabular}{|l|c|c|r|}
\hline Materials (kg) & ( control) & FAC & SFC \\
\hline PC & 50 & 40 & 45 \\
FA & -- & 10 & -- \\
SF & -- & -- & 5 \\
Coarse aggregate & 150 & 150 & 150 \\
Fine aggregate & 150 & 150 & 150 \\
& & & \\
\hline
\end{tabular}

\section{Preparation of test specimens:}

All concrete mixtures were mixed in laboratory mixer for 5 minutes. The size of the cylindrical mold used to cast all the concrete samples was $100 \mathrm{~mm}$ in diameter and $200 \mathrm{~mm}$ in height. After 24 hours, the concrete samples was removed from the molds and cured in water at room temperature for 1, 3, 7, 28, 90 and 180 days. After each curing period, the concrete samples were gradually heated to $45^{\circ} \mathrm{C}$ in an electrically heat oven, and kept at this temperature for the required period of 2,8,12 and 24 hours. At the end of the drying period, the concrete samples were cooled in dissecator for 3 hours before testing. For each data point, three specimens were tested to determine: (1)compressive strength according to ASTM C 39, (2) moisture content according to ASTM F1869-04,(3)absorption, and volume of permeable voids 
according to ASTM C 642. All tests have been done in the research laboratory of chemistry department, Faculty of Science, Al-Azhar University, Assiut branch, Egypt.

1-Compressive Strength ( ASTM C 39): The compressive strength is measured by breaking cylindrical concrete specimens in a compression-testing machine. The compressive strength is calculated from the failure load divided by the crosssectional area resisting the load and reported in unite as MPa.

2-Moisture content ( ASTM F1869-04): Moisture of concrete is the emission of mix water during the drying process of concrete slab. The test is performed by placing a quantity of calcium chloride in an open dish (total weight $W_{1} \mathrm{gm}$ ) and placing the dish on a quantity of clean concrete surface specimen $\left(W_{2} \mathrm{gm}\right)$. The dish is covered by a dome of approximately 9x9x2 inch in height. This dome is sealed to the concrete to prevent normal humidity in the room from affecting the test. The test apparatus is left undisturbed for a period of 72 hours. At the close of the test period the dish is retrieved and weighs $\left(W_{3} \mathrm{gm}\right)$ any weight gain of calcium chloride is attributed to moisture leaving the concrete and being absorbed by the calcium chloride.

$$
\text { Moisture content, }(\%)=\frac{W_{3}-W_{1}}{W_{2}} \times 100
$$

2- Absorption: (ASTM C497): Absorption of concrete is the increase in the weight of concrete due to water in the pores of the material, but not including water adhering to the outside surface of the particles, expressed as a percentage of the dry weight. The test is performed by drying concrete specimens in oven at a temperature of $105^{\circ} \mathrm{C}$ until two successive weighing at intervals of not less than 6 hours. The weight of oven dried specimen was taken immediately upon removal from the oven $\left(W_{d} \mathrm{gm}\right)$.

The dried specimens were placed in a suitable receptacle containing distilled water at a temperature of 10 to $24^{\circ} \mathrm{C}$ and the water was heated up to boiling for 2 hours. Then, the heating was turned off and the specimens were cooled in the water to room temperature by natural loss of heat, for 24 hours. The water-cooled specimens were removed from the water and placed on an open drain rack, and allowed to drain for 1 minute. The remaining superficial water removed by quickly blotting the specimens with a dry absorbent cloth or paper and the saturated surface-dry weight of the specimen in air was taken $\left(W_{s} \mathrm{gm}\right)$. Then take the increase in weight of the boiled specimen over its dry weight as the absorption of the specimen, to be expressed as a percentage of the dry weight.

$$
\text { Absorption, }(\%)=\frac{W_{s}-W_{d}}{W_{d}} \times 100
$$


3-Permeable voids (ASTM C497): Permeable voids are the space between particles in concrete mass not occupied by solid mineral matter. The test is performed by using the weight of oven dried specimen $\left(W_{d} \mathrm{gm}\right)$ and the weight of saturated surface-dry specimen in air $\left(W_{s} \mathrm{gm}\right)$ which was obtained in the previous absorption determination. The specimens were soaked again under water and the buoyant mass of the saturated specimen in water was determined ( $\left.W_{b} \mathrm{gm}\right)$.

$$
\text { Permeable voids, }(\%)=\frac{\mathrm{W}_{\mathrm{s}}-\mathrm{W}_{\mathrm{d}}}{\mathrm{W}_{\mathrm{s}}-\mathrm{W}_{\mathrm{b}}} \times 100
$$

\section{Results and discussion:}

\section{Compressive strength and moisture content:}

The results of compressive strength of blended cement concrete mixtures (control, FAC and SFC) are shown in Figs.[1-4]. The compressive strength values increase with curing period as well as with the period of exposing to high temperature $\left(45^{\circ} \mathrm{C}\right)$. The increase in the strength with time is attributed to an increase in the dense structure of cement due to prolonged hydration of cement aided by continuous curing. Specimens of concrete mixture SFC (contains $10 \%$ silica fume) possess higher compressive strength at all the ages. The compressive strength of FAC specimens (contains 20\% fly-ash) was lower than that of control cement concrete specimens up to 7 days curing. But after 7 days, the compressive strength of FAC specimens was higher than the control cement concrete specimens. The lower in strength of FAC specimens as compared to control cement concrete specimens at the early age may be attributed to the slower pozzolanic reactivity at initial stages which becomes faster after 7 days [24]. The higher strength of the fly-ash and silica fume blended concretes over control cement concrete is attributed to the pozzolanic action which converts calcium hydroxide to $\mathrm{CSH}$. Silica fume being a more reaction pozzolan than fly-ash due to its high silica contents and more fineness [25].

The increase of the compressive strength values with increasing period of exposing to high temperature is attributed to the reduced quantity of moisture in the specimens. Figs.[5-8] show that the moisture content in the specimens decreased with an increasing in period of exposing to high temperature. The reduction in strength due to the presence of moisture is attributed to the disjoining pressure created by the moisture in $\mathrm{CSH}$, which tends to reduce of strength in hydrated cement part. The small crystals of $\mathrm{CSH}$, calcium sulfoaluminate hydrates, and hexagonal calcium 
aluminate hydrates possess large surface area and adhesive capability. These hydration products of Portland cement tend to adhere strongly not only to each other but also to low surface area solids such as calcium hydroxide, anhydrous clinker grains and the coarse aggregate particles [26].

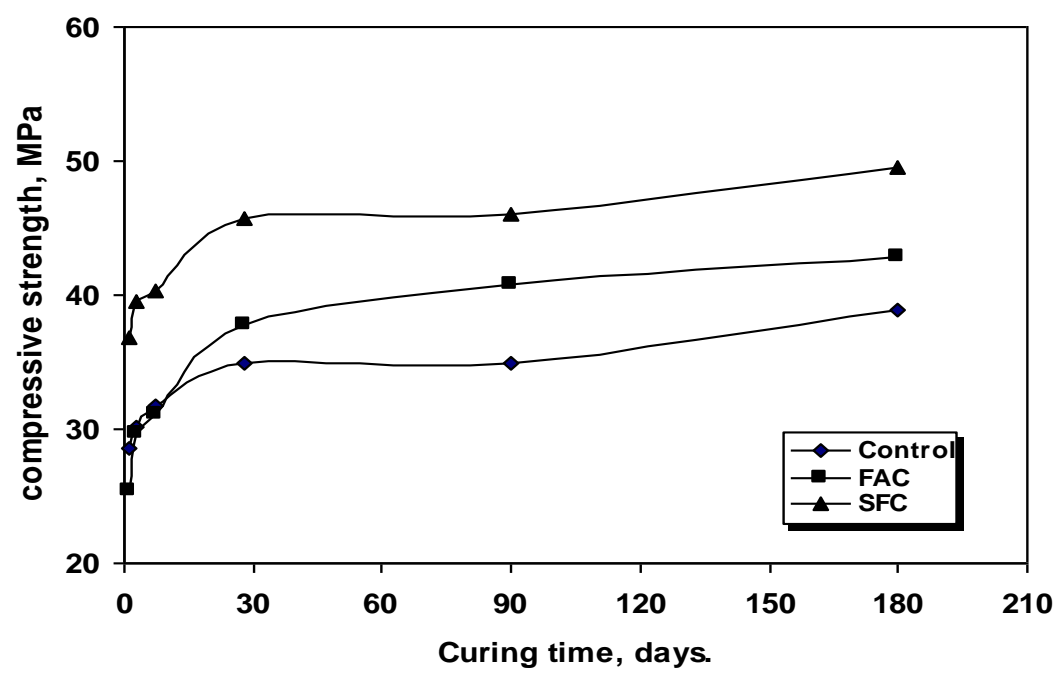

Fig.1: Compressive strength of different concrete mixtures after $2 \mathrm{hrs}$ exposure to $45^{\circ} \mathrm{C}$ as a function of curing time.

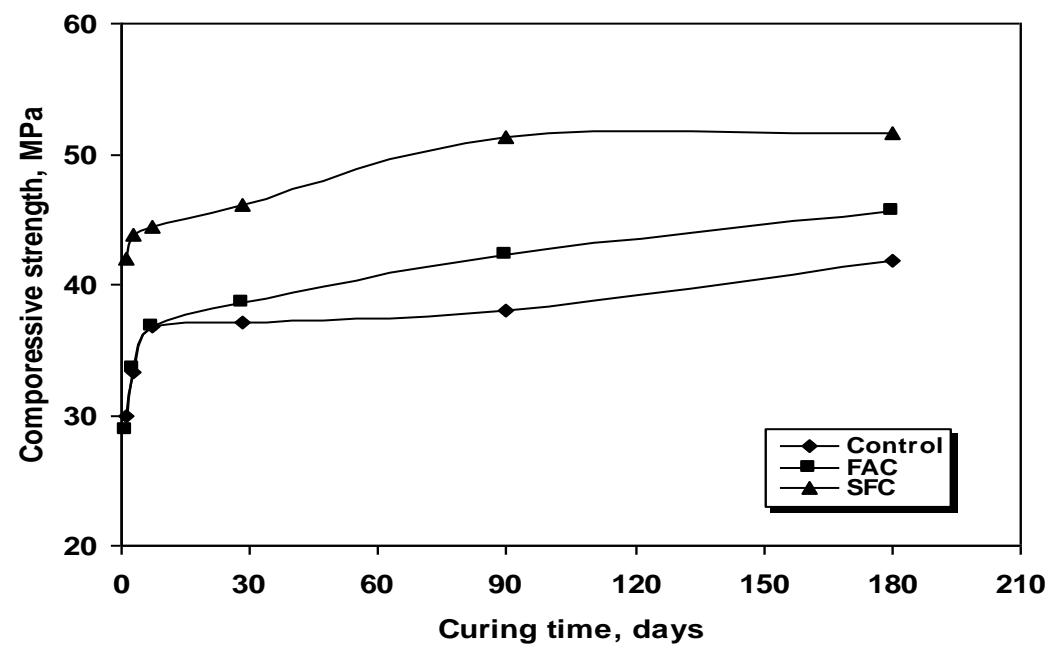

Fig.2: Compressive strength of different concrete mixtures after $8 \mathrm{hrs}$ exposure to $45^{\circ} \mathrm{C}$ as a function of curing time. 


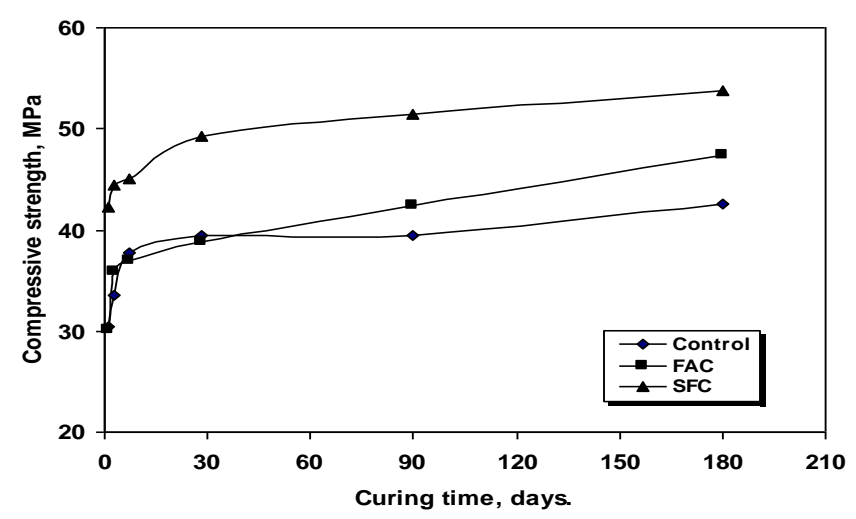

Fig.3: Compressive strength of different concrete mixtures after $12 \mathrm{hrs}$ exposure to $45^{\circ} \mathrm{C}$ as a function of curing time.

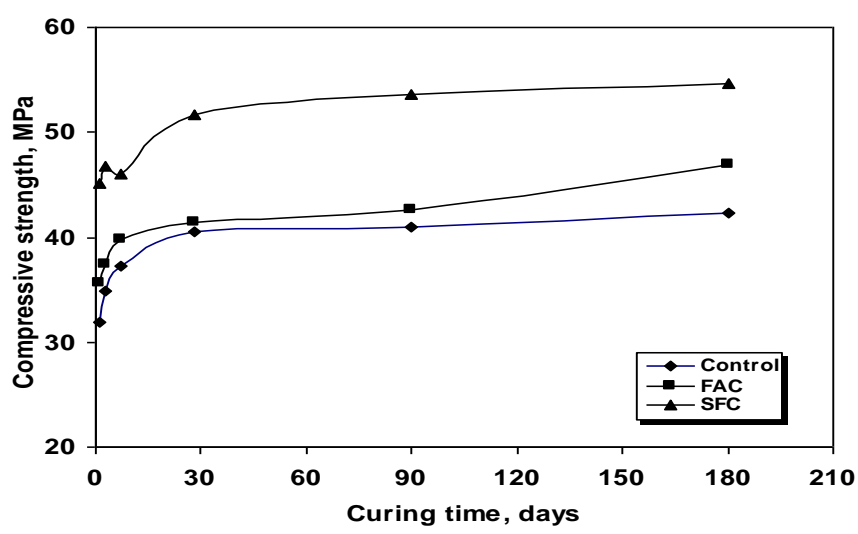

Fig.4: Compressive strength of different concrete mixtures after $24 \mathrm{hrs}$ exposure to $45^{\circ} \mathrm{C}$ as a function of curing time.

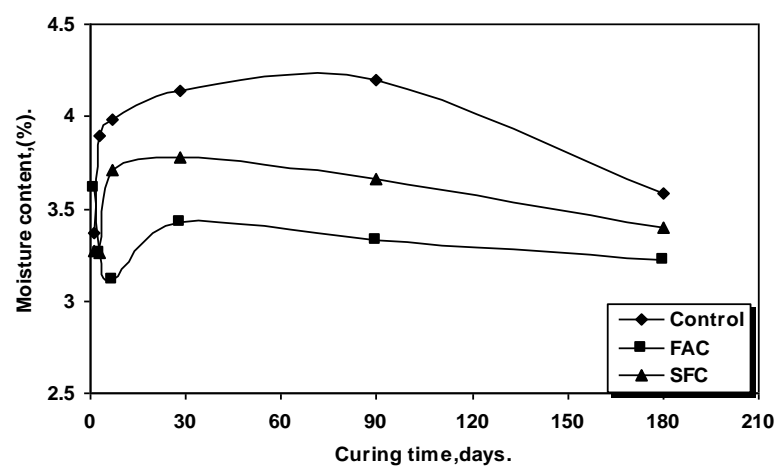

Fig.5: Moisture content of different concrete mixtures after $2 \mathrm{hrs}$ exposure to $45^{\circ} \mathrm{C}$ as a function of curing time. 


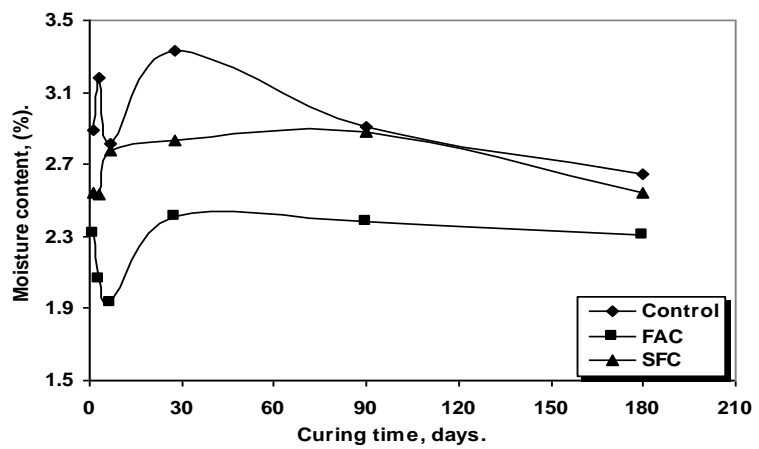

Fig.6: Moisture content of different concrete mixtures after $8 \mathrm{hrs}$ exposure to $45^{\circ} \mathrm{C}$ as a function of curing time.

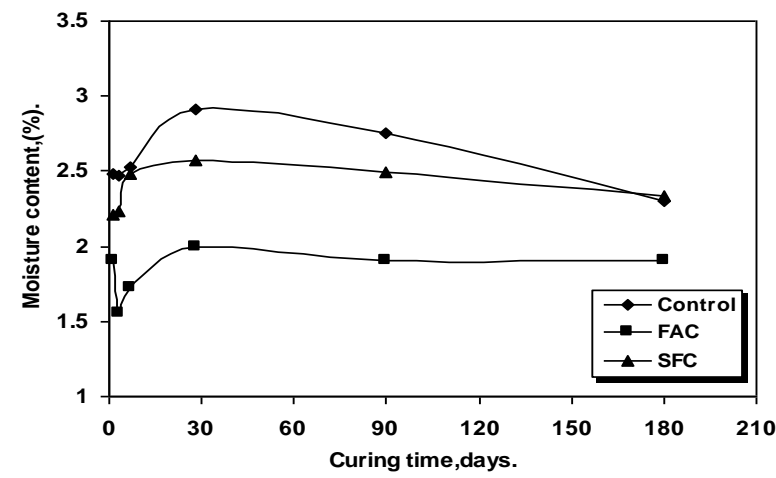

Fig..7: Moisture content of different concrete mixtures after $12 \mathrm{hrs}$ exposure to $45^{\circ} \mathrm{C}$ as a function of curing time.

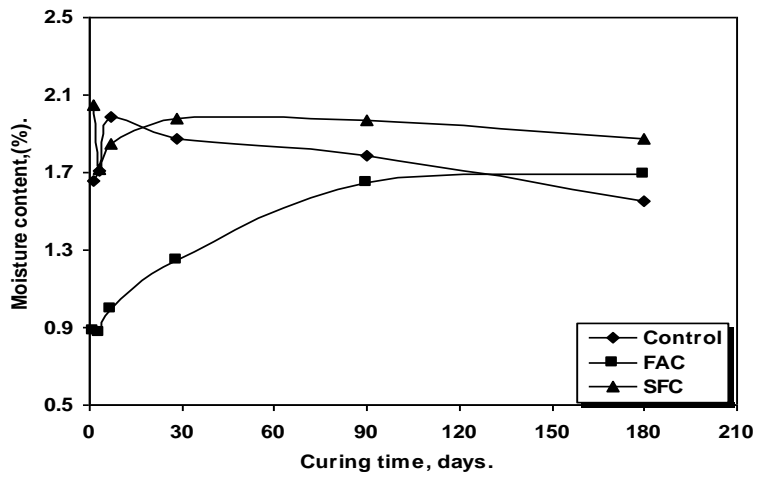

Fig.8 : Moisture content of different concrete mixtures after $24 \mathrm{hrs}$ exposure to $45^{\circ} \mathrm{C}$ as a function of curing time. 


\section{Absorption:}

Figs.(9-12) indicate a decrease in the absorption of blended cement concrete mixtures (control, FAC and SFC) with curing period and an increase in the absorption with increasing period of exposing to high temperature $\left(45^{\circ} \mathrm{C}\right)$. The decrease in absorption, with curing period of FAC and SFC specimens was more significant as compared to control specimens. The water absorption in silica fume blended cement concrete (SFC) specimens was more than that in control specimens up to 7 days of curing, beyond which time the absorption of these specimens was lower than that in control specimens. The absorption capacity of SFC specimens, however, continues to be higher than that of FAC specimens at 180 days of curing. The superior performance of FAC and SFC specimens is attributed to the densification of the cement matrix due to the formation of the secondary CSH as a result of the pozzolanic action [27].

The increase in absorption, with period of exposing to high temperature, of control specimens was greater than the increase in FAC and SFC specimens. This is related to the influence of pore structure of blended cement concretes on the moisture content. The increase in the absorption of concrete specimens with period of exposing to temperature is attributed to the evaporation of moisture from capillary pores. With an increasing of period of exposing to temperature, moisture evaporates leaving more void space for water. Further, since evaporation occurs preferentially from the exposed surface, a saturation gradient develops in the direction of the water movement which depends on the drying temperature. Thus, a dry exposed surface has a large capillary suction force and results in a rapid movement of water into the concrete. Over a period of time the rate of penetration decreases owing to decreasing capillary force resulting from the increasing degree of saturation. The absorption was much smaller in wetter concrete surface[28] and the effect was particularly significant where rain could fall upon the exposed concrete surface.

The higher absorption observed of SFC specimens may be attributed to its very fine pore structure as compared to FAC specimens. The pores, though in a much finer form, are not continuous and therefore do not contribute to diffusion of aggressive ions through the cement matrix to the steel-concrete interface. 


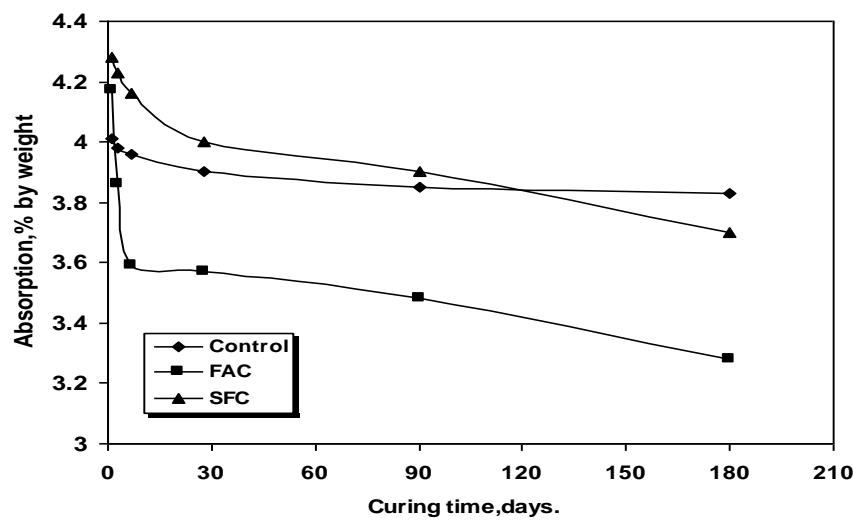

Fig.9: Absorption of different concrete mixtures after $2 \mathrm{hrs}$ exposure to $45^{\circ} \mathrm{C}$ as a function of curing time.

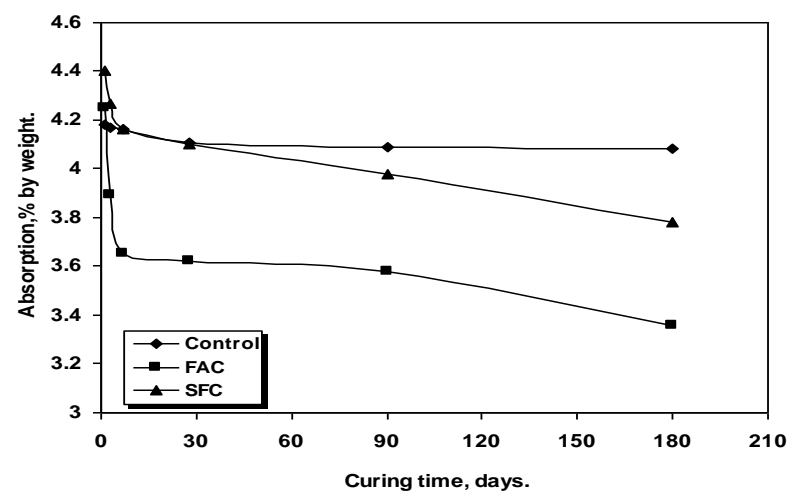

Fig.10: Absorption of different concrete mixtures after 8 hrs exposure to $45^{\circ} \mathrm{C}$ as a function of curing time.

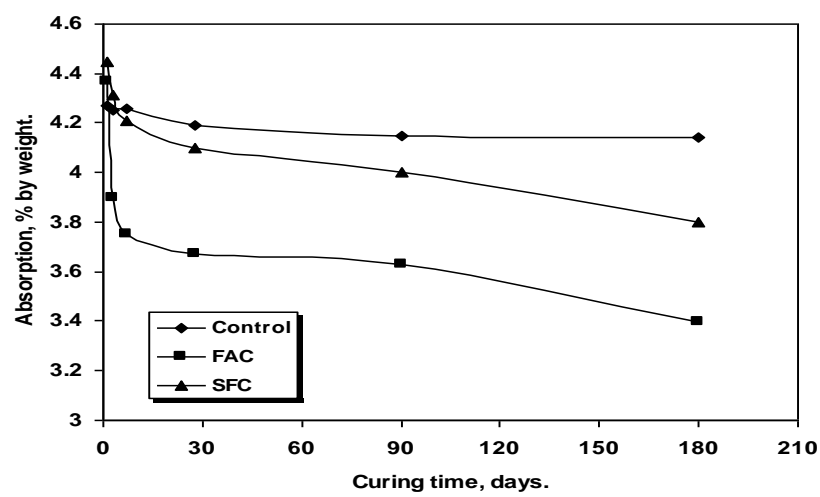

Fig.11: Absorption of different concrete mixtures after $12 \mathrm{hrs}$ exposure to $45^{\circ} \mathrm{C}$ as a function of curing time. 


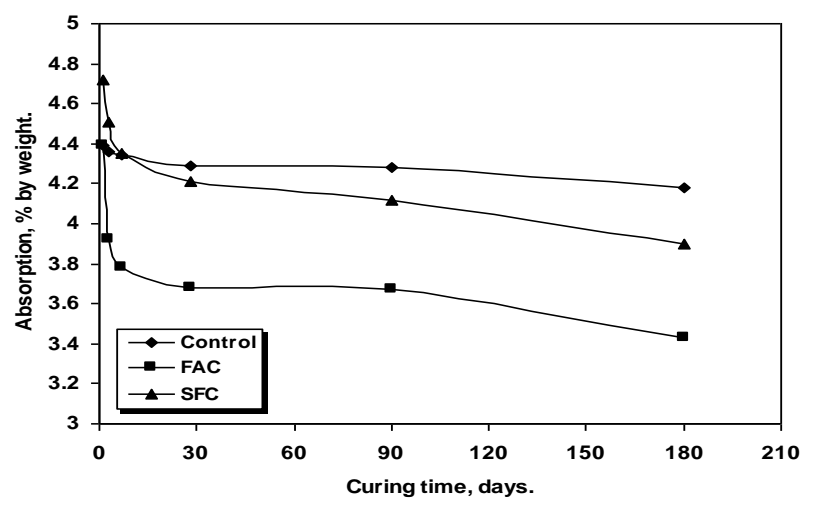

Fig.12: Absorption of different concrete mixtures after $24 \mathrm{hrs}$ exposure to $45^{\circ} \mathrm{C}$ as a function of curing time.

Volume of permeable voids:

The volume of permeable voids in the control, SFC and FAC blended cement concrete mixtures decreased with curing period and increased with period of heat exposing as shown in Figs.(13-16). Variation of volume of permeable voids with curing period, in control, SFC and FAC specimens indicate trends similar to that shown by the absorption capacity. The volume of permeable voids of FAC and SFC specimens were slightly higher than that of control specimens up to 3 days of curing and were lower after this period. The volume of permeable voids of SFC specimens was higher than that in SFC especially after 90 days curing. The reduction in volume of permeable voids with curing was pronounced in FAC and SFC as compared with control specimens. The decrease in volume of permeable voids in all blended cement mixtures, particularly after a curing period of about 7 to 28 days curing is attributed to the pore refinement caused by the formation of the secondary CSH gel during pozzolanic reaction [27].

The exposing of concrete to higher temperature curing has a determined effect on the pore volume of ordinary Portland cement and silica fume in corporate cement pastes, where as the effect is beneficial for cement pastes blended with fly-ash or slag[29]. However, despite the higher volume of pores and absorption, the performance of silica fume cement concrete specimens in terms of sulphate attack was indicated to be superior than the control and fly-ash concrete specimens [30]. The diffusion of aggressive agent, chloride ions in particularly is affected by the diffusion mechanism [31]. Also, there is blocking of pores in concrete specimens due to the production of significant amount of gel during the hydration in pozzolanic 
materials. Further, the pore channels in blended cement concretes have a high tortuosity compared to control specimens. And the chloride ions may be inhibited by interaction with other ions and they pass through the channel.

The above discussion shows that pozzolanic materials are useful in reducing the absorption of cement concrete components. Water absorption is particularly relevant to concrete durability as freeze-thaw damage, sulphate attack, disruptive alkaliaggregate expansion, chloride ingress and reinforced corrosion which require presence of water.

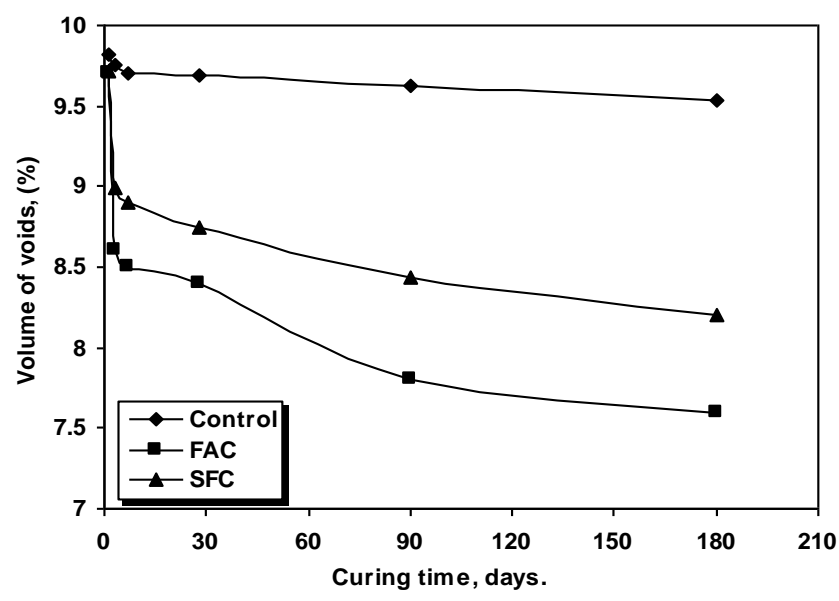

Fig.13: Volume of permeable voids of different concrete mixtures after $2 \mathrm{hrs}$ exposure to $45^{\circ} \mathrm{C}$ as a function of curing time.

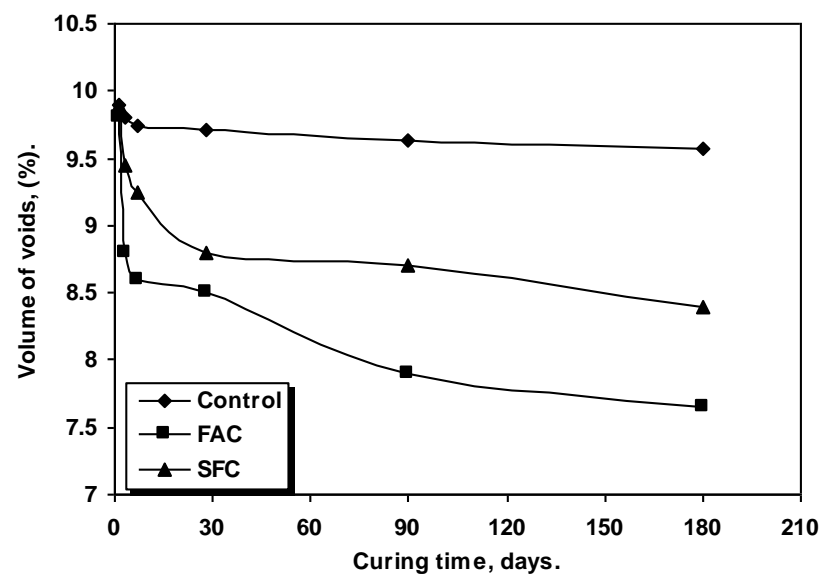

Fig.14: Volume of permeable voids of different concrete mixtures after $8 \mathrm{hrs}$ exposure to $45^{\circ} \mathrm{C}$ as a function of curing time. 


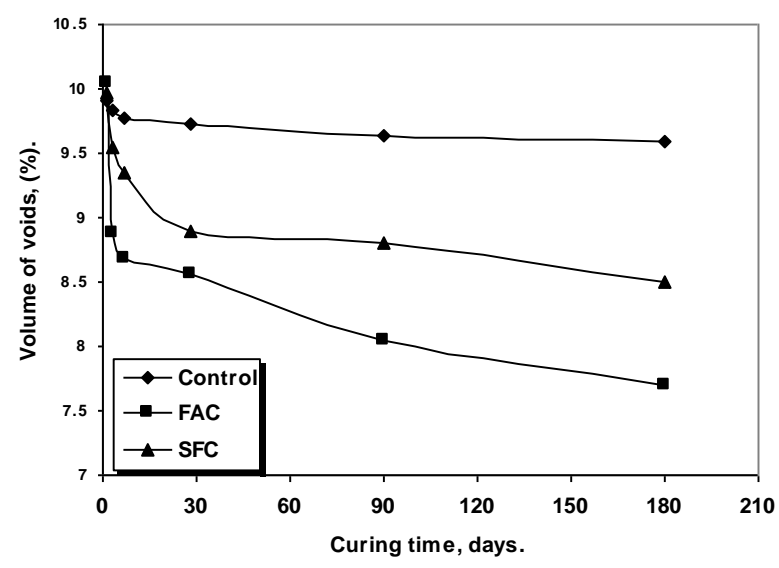

Fig.15: Volume of permeable voids of different concrete mixtures after $12 \mathrm{hrs}$ exposure to $45^{\circ} \mathrm{C}$ as a function of curing time.

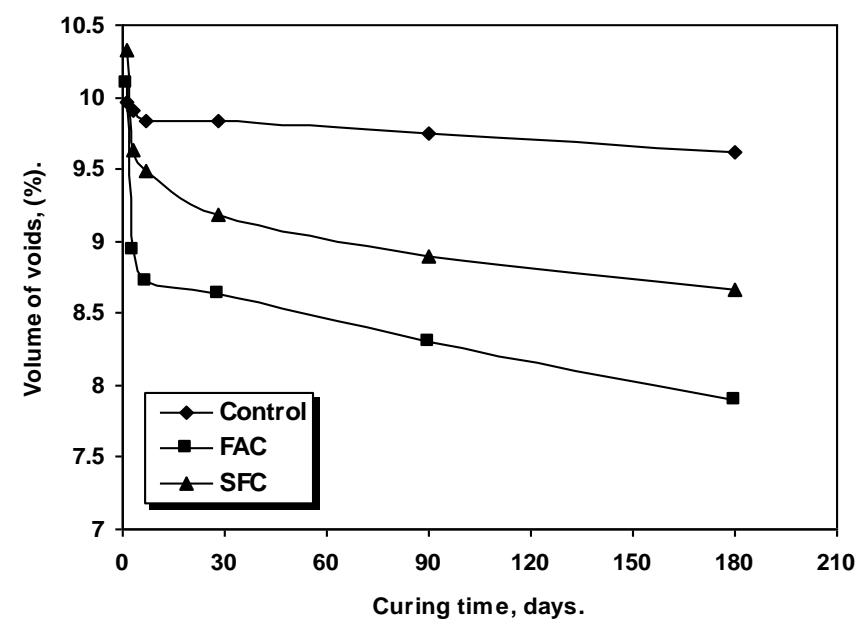

Fig.16: Volume of permeable voids of different concrete mixtures after $24 \mathrm{hrs}$ exposure to $45^{\circ} \mathrm{C}$ as a function of curing time.

\section{Conclusions}

From this study we can concluded that:

1- The compressive strength in control and blended cement concretes increased with increasing curing time and period of exposure to high temperature. Maximum increase in strength occurred in fly-ash cement concrete specimens. 
2- Maximum compressive strength was indicated in silica fume cement concrete specimens. At early ages up to 7 days, the compressive strength of fly-ash cement concrete specimens was lower than that of control cement concrete specimens.

3- Absorption of both control and blended cement concretes decreased with curing time, but increased with exposure to $45^{\circ} \mathrm{C}$. In both fly-ash and silica fume blended cement concretes, there was a significant reduction in absorption after three to seven days of curing.

4- The volume of permeable voids decreased with curing. The reduction was more pronounced in the fly-ash and silica fume blended cement concretes, as compared to control cement concrete.

5- From the absorption and volume of permeable voids data, it can be concluded that pozzolanic materials should be useful in reducing the absorption characteristics of concrete structures, and therefore increasing the durability.

6- The absorption of blended cements being higher at early ages, due to an open pore structure resulting from the reduced quantity of Portland cement and delayed initiation of pozzolanic reaction, structural components should be protected from exposure to water at early ages.

\section{References}

1. A.M. NEVILLE, Properties of Concrete (fourth edition), Pearson Education Limited, England (1999).

2. M. MOURET, A. BASCOUL AND G. ESCADEILlAS, Cem.Concr. Res.,27(3), 345357(1997).

3. K. A. SOUDKI,E.F.EL-SALAKAWY AND N.B. ELKUM, Journal of Materials in Civil Engineering ,13(6), 427-433(2001).

4. M.CERVERA, R.FARIA, J.OLIVER AND T. PRATO, Computers and Structures, $80,1511-1521(2002)$.

5. J.K. KIM, S.H. HAN AND Y.C. SONG, Part I., Cement and Concrete Research, 32, 1087-1094(2002).

6. P.C. AITCIN, Durable concrete: Current practice and future trends, Proceedings of V. Mohan Malhotra Symposium, ACI SP- 144, American Concrete Institute, Detroit, 1993, pp. 85-104.

7. P.KLIEGER, ACI J 54, ,1958) 10631081.

8. K.H. KHAYAT AND P.C. AITCIN, Silica fume in concrete - An overview, ACI SP-132 vol. 2, American Concrete Institute, Detroit (1987) pp. 835-72.

9. V.M. MALHOTRA, G.G. CARETTE AND V. SIVASUNDARAM,: Editor, Advances in concrete technology, Energy, Mines and Resources, Ottawa,925-991(1992). 
10. O.E. GJORV, ACI Mater J 92 (6), 591-598(1989).

11. O.S.B.AL-AMOUDI, M.MASLEHUDDIN AND M.A.BADER, ".Characteristics of silica fume and its impact on concrete in the Arabian Gulf." In: Proceedings of the Sixth International Conference on Deterioration and Repair of Reinforced Concrete in the Arabian Gulf, Bahrain, 2000, pp. 165-80. Also published in Concrete (UK), 35(2),4550(2001).

12. Ch. JATURAPITAKKUL, K. KIATTIKOMOL, V.SATA AND T. LEEKEERATIKUL, Cem.Concr.Res., 34, 549-555(2004).

13. M.F. MOHD ZAINA, AND S.S. RADIN, Cem.Concr.Res., 30, 1283-1287(2000).

14. K.KIATTIKOMOL,C.JATURAPITAKKUL, A.SIRIPANICHGORN, J.WANISRAKUL, P. KEATKRAI P. NIMITYONGSKUL, P. CHINDAPRASIRT, C. TANGSATHIKULCHAI, A.LERTPRASERTWONG AND T. KETRATANABORVON. “ Influence of fineness of classified fly ash on compressive Strength and sulfuric acid attack of mortar, Proceeding of the Third National Concention on Civil Engineering, Songkhla, Thailand, 1997, pp. MAT 2.1- MAT 2.10, in Thai.

15. E.ANGSUWATTANA, C. JATURAPITAKKUL, K.KIATTIKOMOL, A.SIRIPANICHGORN AND T, KETRATANABOVORN, "Use of classical Mac Moh fly-ash in high strength concrete", Supplementary Paoer of the Sixth CANMET/ACI International Conference on Fly Ash, Silica Fume, Slag, and Natural Pozzolans in Concrete, Bangkok, Thailand, 1998, pp.49-60.

16. S.SLANICKA, Cem.Concre.Res., 21, 285-296(1991).

17. R.D.HOOTON, Blended Cements, ASTM STP 897, G. Frohnsdorff, Ed., American Society for Testing and Materials, Philadelphia,1985, pp. 128-143.

18. R.F.FELDMAN, Proceeding, Symposium of fly-ash Incorporation in Cement and Concrete, Materials Research Society, Boston,1981, pp.124-133.

19. C.L.PAGE, N.R.SHORT AND A.EL TARRAS, Cem.Concr.Res., 11,295-306(1981).

20. D.C.MENASHI AND B.ARNON, ACI Materials Journal, May-June, 148-157(1988).

21. E.R.DUNSTAN, Cement,Concrete and Aggregate,3(2), 101-104(1983).

22. M.D.A THOMAS, AND J.D.MTTHEWS, “ Chloride penetration and reinforcement corrosion in marine-exposed fly-ash concrete, Proceeding 3d CANMET/ACI, International Conference on Concrete in a Marine Environment, V.M.Malhorta (Ed.), ACI SP-163,American Concrete Institute, Detroit, 1996, pp.317-338.

23. CH.JATURAPITAKKUL, K.KIATTIKOMOL, V.SATA AND TH. LEEKEERATIKUL, Cem. Concr.Res., 34, 549-555(2004).

24. P.K.MEHTA, "Influence of pozzolanic admixtures on the transition zone in concrete ", International Seminar on Industrial By-product and the Durability of Concrete, Chalmers Univ. of Technology, 1986. 
25. M.A.TAHER, , J.Silicates Industriels Belgium,V.69,No.9(2004).

26. P.K.MEHTA, Concrete.Structure. Properties. And Materials. Prentice-Hall, Inc., New York.

27. D.MANMOHAN AND P.K.MEHTA, Cem.Concr.Aggr., 3(1), 63-67(1981).

28. L.J.PARROTT, Materials and Structure, 22, 284-292(1992).

29. P.S.MANGAT AND J.M.EL-KHATEB, Cem.Concr.Res., 22(6), 813-903(1992).

30. P.S.MANGAT AND J.M.EL-KHATEB, Cem.Concr.Res., 22(6), 1089-1100(1992).

31. S.LI AND D.M.ROY, Cem.Concr.Res., 16(3), 779-759(1986). 
دراسة تأثير الرماد المتطاير وتراب السيليكا على خواص الخرسانة المعرضة للحرارة المرتفعة محمود أحمد طاهر

كلية العلوم - قسم الكيمياء- جامعة الأزهر - فرع أسيوط

\section{ملخص البحث}

إن تعرض الخرسـانة السى درجـات حـرارة مرتفعـة يتسـبب فى عدد مسن التأثيرات الضــارة على الأداء

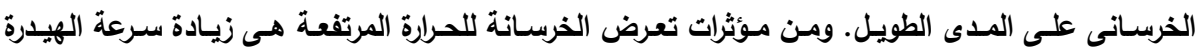

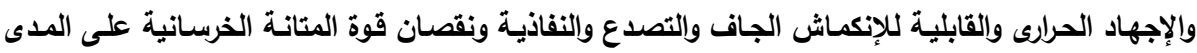

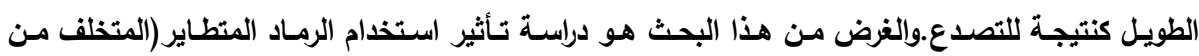

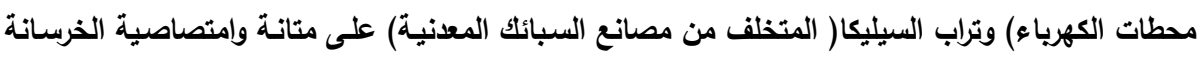

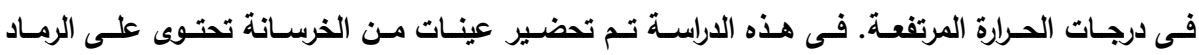
المتطايربنسبة 20\% وأخرى تحتوى على تراب السيليكا بنسبة 10\% وعينـات أخرى من الخرسـانة العاديـة

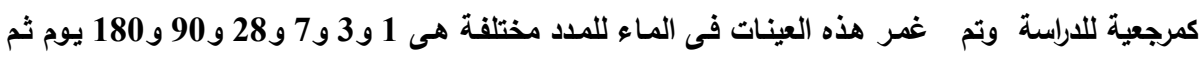

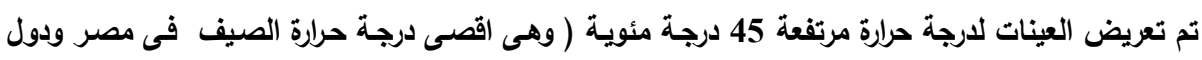

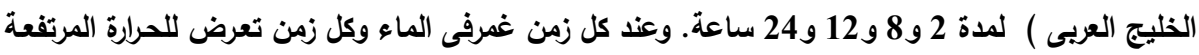

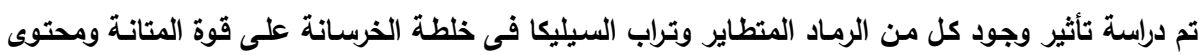

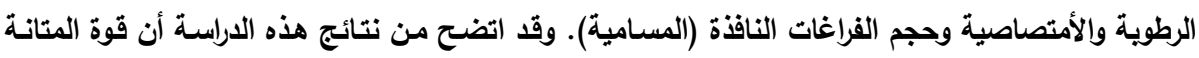

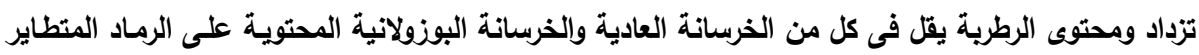

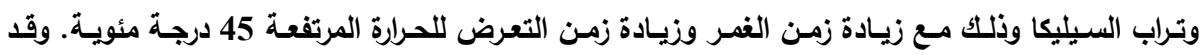

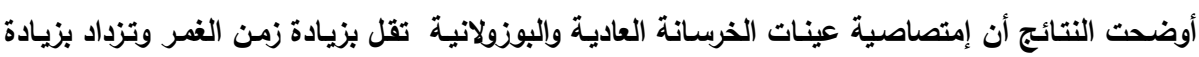

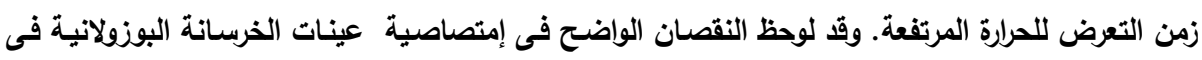

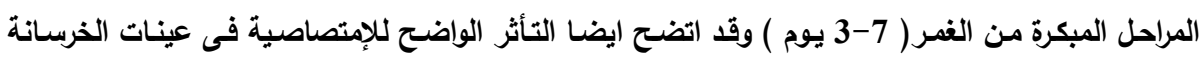

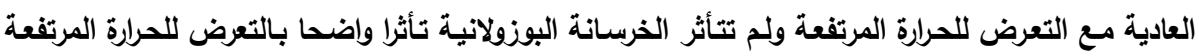

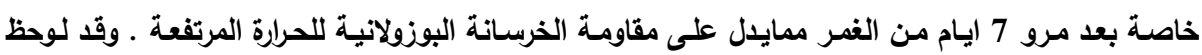

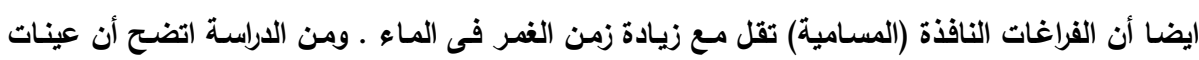

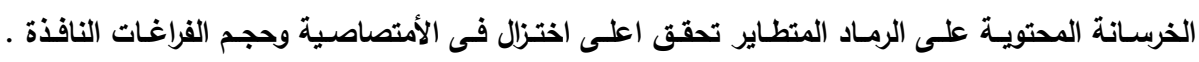

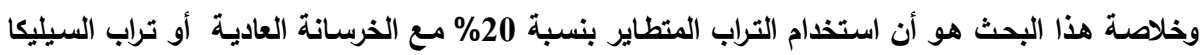

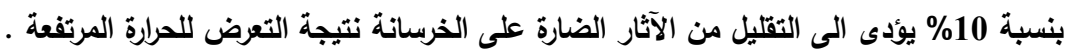

